\title{
BACTERIAL FAUNA ASSOCIATED WITH THE BLOW FLY, Chrysomya megacephala (F.) IN UBON RATCHATHANI PROVINCE OF NORTHEAST THAILAND
}

\section{TARINEE CHAIWONG1, THANYAKARN SRIVORAMAS'1, KOM SUKONTASON², MICHELLE R. SANFORD³ AND KABKAEW L. SUKONTASON2}

${ }^{1}$ College of Medicine and Public Health, Ubon Ratchathani University, Warinchamrap, Ubon Ratchathani, 34190, Thailand.

${ }^{2}$ Faculty of Medicine, Chiang Mai University, Muang, Chiang Mai, 50200, Thailand.

3Pathology, Microbiology and Immunology, University of California, Davis, California.

*Corresponding Author: Email- tarinee.4004@gmail.com

Received: May 11, 2012; Accepted: May 21, 2012

\begin{abstract}
The objective of the current study was to isolate and identify the bacterial fauna associated with populations of the Oriental latrine fly, Chrysomya megacephala, collected in the Muang district of Ubon Ratchathani province, an area of high diarrhoeal disease incidence. A total of 294 flies were collected from September 2010-August 2011 using a sterilized insect sweep net at each collection site including freshfood markets, garbage piles, restaurants, school cafeterias and paddy fields of Muang Ubon Ratchathani in the Ubon Ratchathani province. Each specimen was transferred into individual sterile glass vials for bacterial isolation using standard bacterial isolation techniques from the external surfaces of the flies of the 294 flies collected, $98.64 \%$ were found to be carrying multiple species of bacteria. A total of 15 bacterial genera were isolated, including both potentially pathogenic and non-pathogenic bacteria.The most common bacterium isolated from C. megacephala was coagulase-negative staphylococci ( $80.27 \%$ ) followed by Streptococcus group D non-enterococci $(69.05 \%)$. Among these were human pathogenic enteric bacteria including Escherichia coli 0157:H7 (EHEC) and Salmonella typhi with the prevalence rates in flies being $3.06 \%$ and $20.88 \%$ respectively. Furthermore, other human pathogens were found such as Staphylococcus aureus and Pseudomonas aeruginosa. The present study demonstrates the potential of $C$. megacephala to vector pathogenic enteric bacteria to humans .
\end{abstract}

Key words- Blowfly, bacterial fauna, diarrhoeal disease, Ubon Ratchathani province.

Citation: Tarinee Chaiwong, et al. (2012) Bacterial Fauna Associated With The Blow Fly, Chrysomya megacephala (F.) in Ubon Ratchathani Province of Northeast Thailand. International Journal of Parasitology Research, ISSN: 0975-3702 \& E-ISSN: 0975-9182, Volume 4, Issue 1, pp.-71-74.

Copyright: Copyright@2012 Tarinee Chaiwong, et al. This is an open-access article distributed under the terms of the Creative Commons Attribution License, which permits unrestricted use, distribution and reproduction in any medium, provided the original author and source are credited.

\section{Introduction}

Chrysomya megacephala is the blow fly of medical importance which is widely distributed throughout Asia, Australasia, South Africa and South America [1-2]. It is one species of a group of synanthropic flies that have been reported to be associated with unsanitary conditions and involved in the dissemination of human enteropathogens in the environment [3]. In Thailand, it is the most abundant blow fly species collected in surveys of synanthropic flies [4-6]. The greatest medical importance of $C$. megacephala is its potential as a mechanical carrier of various pathogens that may cause disease in humans. C. megacephala has been reported as mechanical carriers of multiple pathogens including Aer- omonas hydrophila, A. obria, Citrobacter freundii, Edwardsilla tarda, Enterobacter cloacae, Eschericia coli, Klebsiella pneumoniae, Proteus mirabilis, P. morganii, P. vulgaris, Providencia alcalifaciens, $P$. aeruginosa, $S$. typhi, Shigella dysenteriae, $S$. aureus,Vibrio cholerae non-01 and Viridan streptococci [7-9]; protozoa including Chilomastix mesnili, Endolimax nana, Entamoeba histoIytica, Iodamoeba butschlii and Trichomonas hominis [7,10]; and the helminth eggs Ascaris sp.,Hymenolepis diminuta, Toxocara $\mathrm{sp}$. and Trichuris trichiura [7-8, 11]. In the past, E. coli, Salmonella sp., Shigella sp. and Vibrio cholerae non-01 have usually been found to be the principal bacterial pathogens responsible for diarrhoeal disease in humans [12-14]. 
Current research involving the distribution and abundance of medically important flies in Thailand is limited and incomplete regarding the variety of ecological zones of the country. C. megacephala has a reported association as a mechanical vector of pathogens in Chiang Mai in the north region of Thailand [15-16]. That region is characterized by more temperate climate conditions and higher elevation than the other regions of Thailand, where upland rice production and field crops are the predominant forms of agriculture. In contrast, the climate of the Northeast region is characterized by longer periods of hot and dry weather where livestock production and rice paddy cultivation are the main agricultural practices. The differences in both climate and agricultural commodities in these two regions of Thailand may have significant impacts on fly populations, bacterial fauna and the interaction between these factors. In this study, C. megacephala was assessed as a potential mechanical vector of the bacteria associated with diarrhoeal disease in the Northeast region, which has the second highest proportion of total cases of diarrhoeal disease reported among all regions of the country. Therefore, the objective of this study was to isolate and identify the bacterial fauna associated with populations of $C$. megacephala, collected in Muang district of Ubon Ratchathani province, an area of high diarrhoeal disease incidence.

\section{Materials and Methods \\ Collection of flies}

Total 294 adults C. megacephala were captured with a sterile insect sweep net at five collection sites-fresh-food markets, garbage piles, restaurants, school cafeterias and paddy fields of Muang district of Ubon Ratchathani province, Northeast part of Thailand, from September 2010-August 2011. Each specimen was transferred into individual 20 milliliters sterile glass vials $(2.5 \mathrm{~cm}$ diameter, $6 \mathrm{~cm}$ height) using sterile forceps. Each vial was immediately covered with a sterile cap. The vials containing flies were transported within one hour to the College of Medicine and Public Health, Ubon Ratchathani University. In the laboratory, all fly specimens were sacrificed by placing them into a freezer set at $-20^{\circ} \mathrm{C}$ for 15 minutes. Species identification was confirmed under a stereo dissecting microscope using the keys of Tumrasvin et al. [17] and Kurahashiand Chowanadisai [2] while maintaining a sterile technique to preserve the bacteria associated with the fly sample.

\section{Isolation of bacteria from fly samples}

Bacteria each fly were isolated using standard bacterial isolation techniques from the outside surface of each individual. Two milliliters of sterile buffer peptone water were added to each vial and then shaken vigorously for 2 minutes to create a wash from each fly. Subsequently, $0.1 \mathrm{ml}$ of the wash solution was inoculated onto selective culture media plates. Selective media were used to differentiate among closely related groups of bacteria and isolate specific bacteria from a mixed population. The following media were used in this study: Phenylethyl alcohol agar plates (PEA) for the isolation of gram positive cocci [18], MacConkey agar plates for the isolation of gram negative bacilli including Enterobacteriaceae, Salmonella and Shigella (SS) agar plates and Selenite-F broth for the isolation of Salmonella sp. and Shigella sp., Thiosulfate citrate bile salt agar plates (TCBS) and alkaline peptone water for the isolation of Vibrio sp. The plates were incubated for $24-48$ hours at $37^{\circ} \mathrm{C}$. Three single isolates were then picked from these culture plates for further bacterial identification. The isolated bacteria were then identified by morphological and biochemical tests using the methods from Bergey's Manual of Determinative Bacteriology [19].

\section{Results}

A total of 294 flies were collected from fresh-food markets, garbage piles, restaurants, school cafeterias and paddy fields of Muang Ubon Ratchathani in the Ubon Ratchathani province. Of these, $98.64 \%$ were found to be carrying multiple species of bacteria. A total of 15 bacterial genera were isolated in this study, including 10 gram-negative bacterial genera and five grampositive bacterial genera. Different potentially pathogenic and nonpathogenic bacteria were identified and are presented in Table-1. The most common bacterium isolated from C. megacephala was coagulase-negative staphylococci $(80.27 \%)$ followed by Streptococcus group D non-enterococci (69.05\%). Furthermore, other human pathogens were found such as $S$. aureus were isolated from $28(9.25 \%)$ flies and $P$. aeruginosa were isolated from 39 (13.27\%) flies (Table-1). The highest percentage of total bacteria isolated C. megacephala were collected from restaurants followed by paddy fields, school cafeterias, garbage piles and fresh-food market, respectively (Figure-1).

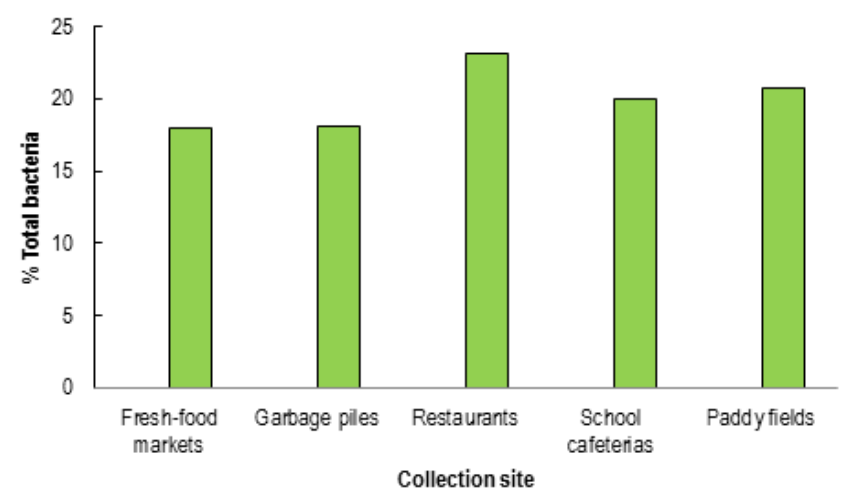

Fig. 1- Percentage of total bacteria isolated from C. megacephala collected from fresh-food markets, garbage piles, restaurants, school cafeterias and paddy fields of Muang Ubon Ratchathani in the Ubon Ratchathani province, Northeast Thailand.

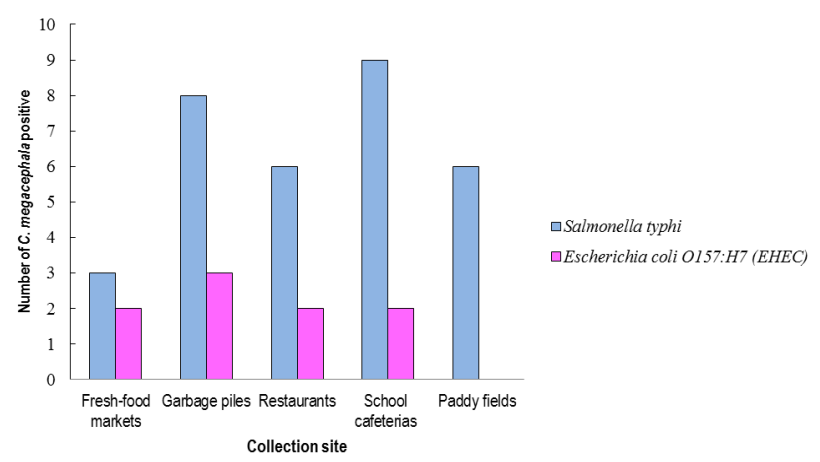

Fig. 2- Number of $C$. megacephala positive for Salmonella typhi and Escherichia coli 0157:H7 (EHEC) collected from fresh-food markets, garbage piles, restaurants, school cafeterias and paddy fields of Muang Ubon Ratchathani in the Ubon Ratchathani province, Northeast Thailand. 
Among the bacteria identified were two important human pathogenic enteric bacteria including E. coli 0157:H7 (EHEC) and S. typhi, isolated from $9(3.06 \%)$ and $32(10.88 \%)$ flies, respectively (Table-1). The number of C. megacephala positive for S. typhi were higher than E. coli 0157:H7 (Figure-2). The highest number of flies positive for $S$. typhi were found at the school cafeterias, whereas the highest number of flies positive for E. coli 0157:H7 were collected from garbage piles. Moreover, E. coli 0157:H7 was not isolated from flies collected from paddy fields (Table-1 and Figure-2). Nevertheless, various bacterial pathogens responsible for causing other human diseases were found, with the list of such species in Table-1.

\section{Discussion}

In this study, C. megacephala were shown to be carriers of multiple species of bacteria, demonstrating their potential to be mechanical vectors of human pathogenic bacteria. Multiple species of bacteria were isolated from a majority of the flies (98.64\%) of the flies collected in the study indicating that this fly species is a potential mechanical vector of multiple pathogens. This has been previously suggested in reports by Greenberg [7] and Förster et al [20]. Most of the bacteria recovered from this fly species are important human pathogens, known to produce diseases such as food poisoning, diarrhea and skin infection in humans and animals.

There are several reasons that may enhance the ability of $C$. megacephala to act as a carrier of human pathogens, of which the main one is the fact that adults can feed on variable food such as animal manure, trash, human excrement and other decaying materials. The present study shows that the highest percentage of total bacteria isolated from C. megacephala were collected from restaurants. These types of sites presented many attractive resources for Chrysomya, such as meat and fish as indicated by the use of these materials as bait for collection [5]. In a study by Bunchu et al.[21] in C. megacephala, they found that males and females were attracted to a wide variety of animal meat products as well as fresh fruits which are likely to be found in restaurants during food preparation. The house fly Musca domestica, another medically important synanthropic fly, has been found capable of carrying bacteria from dumpsters outside of restaurants to food within the restaurants [22]. If these organisms are not prevented from entering the food preparation and consumption areas, they can introduce a serious risk in disease transmission.

The results of this study demonstrated that $C$. megacephala collected from five collection sites were contaminated with Salmonella sp, Shigella sp, E. coli 0157:H7 and S. typhi, important agents of gastroenteritis. These bacteria have been isolated from Chrysomya on several occasions [23]. Interestingly, previous studies by Sukontason et al. [9, 15-16] did not isolate Salmonella sp. and Shigella sp. from C. megacephala collected in Chiang Mai, in the northern part of Thailand. However, V. cholera non-01, another important enteric pathogen isolated by Sukontason et al. [9,1516] was not isolated from C. megacephala in the present study. This suggests that other factors such as differences in climate or types of agricultural production may influence the pathogenic bacteria present on synanthropic flies and may affect their potential to serve as mechanical carriers in these areas. Flies were positive for $S$. typhi at all sites, but this pathogen dominated in garbage piles and at school cafeterias; locations with access to a variety of decomposing materials, including vegetables and other decaying organic matter. E. coli 0157:H7 was not found in paddy fields, but we have identified other $E$. coli strains on flies from this area.

Some bacterial species isolated from $C$. megacephala produce foodborne illness and other potential pathogenic agent to humans. $S$. aureus is a part of the natural human skin flora, however toxinexpressing strains can cause skin infection and food poisoning [24]. Bacillus sp. is also causative agent for diarrhea. Klebsiellasp. and $P$. aeruginosa causes hospital acquired infection and is also associated with inflammatory conditions of upper respiratory tract. Enterobacter sp. and Proteus sp. are also known to cause urinary tract infections [25]. Burkholderia pseudomallei, the organism causing melioidosis, has been isolated from $C$. megacephala collected in Malaysia [27]. In present study, B. pseudomallei was not found in any samples from any collection sites, these located in the northeastern regions of Thailand, the area of highest prevalence for this microorganism in Thailand [28].

In conclusion, this study demonstrates the potential of C. megacephala to serve as a mechanical carrier of pathogenic enteric bacteria. The results show the ability of this fly to carry bacteria that are of importance in causing not only foodborne illness but also other potential pathogenic agent to humans. The bacteria described in this study were obtained from C. megacephala within human habitats presenting a potential human risk for disease transmission. Future studies should address the impact of climatic, temporal and fly species interactions on the bacteria carried by synanthropic flies in this region of Thailand.

\section{Acknowledgements}

This study was financially supported by the Thailand Research Fund, Office of the Higher Education Commission and Ubon Ratchathani University (MRG5380283 to TC). We thank the College of Medicine and Public Health, Ubon Ratchathani University for facilities.

\section{References}

[1] Wells J.D. and Kurahashi H. (1994) Jpn. J. Sanit. Zool., 45, 303-9.

[2] Kurahashi H. and Chowanadisai L. (2001) Species Divers, 6, 185-242.

[3] Graczyk T.K., Knight R., Gilman R.H. and Cranfield M.R. (2001) Microbes and Infection, 3, 231-235.

[4] Sucharit S., Tumrasvin W. and Vutikes S. (1976) Southeast Asian J. Trop. Med. Public Health, 7, 85-90.

[5] Tumrasvin W., Sucharit S. and Kano R. (1978) Bull. Tokyo Med Dent., 25, 77-81.

[6] Sucharit S. and Tumrasvin W. (1981) Jpn J. Sanit. Zool., 32, 281-5.

[7] Greenberg B. (1971) Flies and disease, I. Ecology, classification and biotic associations. Princeton University Press, Princeton, New Jersey.

[8] Sulaiman S., Sohadi A., Yunus H. and Iberahim R. (1988) Med Vet Entomol., 2, 1-6.

[9] Sukontason K.L., Bunchoo M., Khantawa B., Piangjai S., Rongsriyam Y., Sukontason K. (2007) Southeast Asian. J. Trop. Med. Public. Health., 38,38-44. 
[10]Greenberg B. (1973) Flies and disease. Biological and disease transmission. Princeton University Press, Princeton, New Jersey.

[11]Monzon R.B., Sanchez A.R., Tadiaman B.M., Najos O.A., Valencia E.G., de Rueda R.R., Ventura J.V. (1991) Southeast Asian. J. Trop. Med. Public. Health., 22, 222-8.

[12]Gordon J.E., Behar M., Scrimshaw N.S. (1964) Bull WIdHIth Org., 31, 1-7.

[13]Sheth M., Dwivedi R. (2006) Indian J. Pediatr., 73, 61-4.

[14]Ashbolt N.J. (2004) Toxicology, 198, 229-338.

[15]Sukontason K., Bunchoo M., Khantawa B., Piangjai S., Sukontason K., Methanitikorn R., Rongsriyam Y. (2000a) Southeast Asian. J. Trop. Med. Public. Health., 31, 157-61.

[16]Sukontason K.L., Bunchoo M., Khantawa B., Sukontason K., Piangjai S., Choochote W.(2000b) J. Vec. Ecol., 25, 114-7.

[17]Tumrasvin W., Kurahashi H., Kano R. (1979) Bull. Tokyo Med Dent Univ., 26, 243-72.

[18]Cappuccino J.G. and Sherman N. (2002) Microbiology A Laboratory Manual. $6^{\text {th }}$ Edition. Benjamin Cummings. CA, USA.

[19]Bergey D.H., Holt J.G., Krieg N.R., Sneath P.H.A. (1994) Bergey's Manual of Determinative Bacteriology. 9th edition. Lippincott, Williams \& Wilkins. MI, USA.
[20]Förster M., Klimpel S., Mehlhorn H., Sievert K., Messler S., Pfeffer K. (2007) Parasitol. Res., 101, 243-6.

[21]Bunchu N.,SukontasonK.L., OlsonJ.K.,KurahashiH., Sukontason K. (2008) Parasitol. Res., 102, 419-429.

[22]Butler J.F., Garcia-Maruniak A., Meek F., Maruniak J.E. (2010) Florida Entomol., 93, 218-23.

[23]Paraluppi N.D., Vasconcelos J.C., Aquino J.S., Castellon E.G., Silva MS.B. (1996) Acta. Amazonica., 26, 93-6.

[24]Förster M, Sievert K, Messler S, Klimpel S, Pfeffer K. (2009) J. Med. Entomol., 46, 1164-6.

[25]Nazni W.A., Seleena B., Lee H.L., Jeffery J.T,Rogayah T.A., Sofian M.A. (2005) Trop. Biomed., 22, 225-31.

[26]Murray P.R., Rossenthal K.S., Pfaller M.A. Medical Microbiology $6^{\text {th }}$ ed. Mosby Elserier, 2009.

[27]Sulaiman S. Othman M.Z., Aziz A.H. (2000) J. Vector. Ecol., 25, 90-3.

[28]PaveenkittipornW., Apisarnthanarak A., Dejsirilert S., Trakulsomboon S., Thongmali O., Sawanpanyalert P., Aswapokee N. (2009) J. Med. Assoc. Thai., 92, 46-52.

Table 1-Bacteria isolated from C. megacephala collected from fresh-food markets, garbage piles, restaurants, school cafeterias and paddy fields of Muang Ubon Ratchathani in the Ubon Ratchathani province, Northeast Thailand

\begin{tabular}{|c|c|c|c|c|c|c|}
\hline \multirow[b]{2}{*}{ Bacteria isolated } & \multicolumn{6}{|c|}{ No. of bacterial species isolated from C. megacephala from each site type } \\
\hline & Fresh-food markets & Garbage piles & Restaurants & School cafeterias & Paddy fields & Total of flies $(\%)$ \\
\hline Citrobacter sp. & 11 & 14 & 21 & 14 & 22 & $82(27.89)$ \\
\hline Enterobacter sp. & 2 & 1 & 1 & 4 & 4 & $12(4.08)$ \\
\hline Escherichia coli & 17 & 15 & 25 & 19 & 14 & $90(30.61)$ \\
\hline Klebsiella sp. & 30 & 28 & 27 & 27 & 31 & $143(48.64)$ \\
\hline Morganella sp. & 7 & 8 & 9 & 6 & 12 & $42(14.29)$ \\
\hline Proteus sp. & 25 & 25 & 53 & 36 & 41 & $180(61.22)$ \\
\hline Providencia sp. & 4 & 8 & 8 & 9 & 10 & $39(13.27)^{\prime}$ \\
\hline Pseudomonas aeruginosa & 13 & 19 & 16 & 12 & 11 & $71(24.15)$ \\
\hline Salmonella sp. & 8 & 12 & 14 & 13 & 16 & $63(21.43)$ \\
\hline Shigella sp. & 11 & 4 & 4 & 7 & 7 & $33(11.22)$ \\
\hline Bacillus sp. & 33 & 39 & 47 & 43 & 40 & $202(68.71)$ \\
\hline Entercoccus sp. & 14 & 14 & 16 & 9 & 14 & $67(22.79)$ \\
\hline Staphylococcus aureus & 9 & 1 & 11 & 5 & 2 & $28(9.52)$ \\
\hline Coagulase-negative staphylococci & 42 & 44 & 52 & 50 & 48 & $236(80.27)$ \\
\hline Streptococcus group $D$ non-enterococci & 45 & 35 & 42 & 42 & 39 & $203(69.05)$ \\
\hline Salmonella typhi* & 3 & 8 & 6 & 9 & 6 & $32(10.88)$ \\
\hline Escherichia coli 0157:H7(EHEC) ${ }^{*}$ & 2 & 3 & 2 & 2 & 0 & $9(3.06)$ \\
\hline Total negative flies & 0 & 2 & 0 & 0 & 2 & $4(1.36)$ \\
\hline Total flies examined & 60 & 60 & 60 & 59 & 55 & 294 \\
\hline
\end{tabular}

